\title{
Vitamin A deficiency and factors associated with retinol levels in public school students
}

\author{
Deficiência de vitamina A e aspectos associados \\ aos niveis de retinol em estudantes \\ de escolas públicas
}

Adeíldes Bezerra Moura de LIMA

Laís Spíndola GARCÊZ²

lara Katrynne Fonseca OLIVEIRA ${ }^{3}$

Marize Melo dos SANTOS ${ }^{1}$

Suzana Maria Rebelo Sampaio DA PAZ4

Adriana de Azevedo PAIVA ${ }^{1}$

\section{A B S T R A C T}

\section{Objective}

To estimate the prevalence of vitamin A deficiency and determine the socioeconomic and demographic factors associated with serum retinol levels in public school students.

\section{Methods}

This cross-sectional study included 245 students from the urban and rural areas of the city of Teresina, Piaui, Brazil. Socioeconomic data were collected using a form. Serum retinol level was determined by high-performance liquid chromatography and classified according to the cut-off points provided by the World Health Organization. All statistical tests had a significance level of $5 \%$.

\section{Results}

The prevalence of vitamin A deficiency (retinol level $<0.70 \mu \mathrm{mol} / \mathrm{L})$ was $9.8 \%(95 \% \mathrm{Cl}=7.9-10.0)$. The prevalences of low and acceptable retinol levels $(<1.05 \mu \mathrm{mol} / \mathrm{L})$ were higher in students aged $12-14$ years living in households

\footnotetext{
1 Universidade Federal do Piauí, Departamento de Nutrição, Programa de Pós-Graduação em Alimentos e Nutrição. Campus Universitário Ministro Petrônio Portella, Bloco 13, Ininga, 64049-550, Teresina, PI, Brasil. Correspondência paral Correspondence to: AA PAIVA. E-mail: <aapaiva@ufpi.edu.br>.

2 Universidade Federal da Bahia, Escola de Nutrição, Programa de Pós-Graduação em Alimentos, Nutrição e Saúde. Salvador, BA, Brasil.

${ }^{3}$ Universidade Federal do Piauí, Departamento de Nutrição, Curso de Nutrição. Teresina, PI, Brasil.

${ }^{4}$ Faculdade Santo Agostinho, Curso de Nutrição. Teresina, PI, Brasil.

Article based on the master's thesis of ABM LIMA, intitled "Niveis de retinol e fatores associados à sua deficiência em estudantes de Teresina, Piauí". Universidade Federal Piauí; 2013.
} 
without piped water supply ( $p>0.05)$. Water well or other untreated water sources were the factors most strongly associated with low retinol levels $(\mathrm{OR}=3.28 ; 95 \% \mathrm{Cl}=1.48-7.28 ; p=0.003)$.

\section{Conclusion}

Vitamin A deficiency was characterized as a mild public health problem in the students, indicating the need of actions that address this issue in schools and of studies with larger samples to investigate the problem at the municipal and state levels. Untreated water intake, a possible source of waterborne illnesses, contributed to lower retinol levels.

Keywords: Indicators. Students. Vitamin A. Vitamin A deficiency.

\section{R E S U M O}

\section{Objetivo}

Estimar a prevalência de deficiência de vitamina A e analisar fatores socioeconômicos e demográficos associados aos níveis de retinol séricos em estudantes de escolas públicas.

\section{Métodos}

Estudo transversal conduzido com 245 estudantes da zona urbana e rural da cidade de Teresina, Piauí. Dados socioeconômicos foram coletados em formulário e o retinol sérico determinado por cromatografia líquida de alta resolução e classificado segundo os pontos de corte da Organização Mundial de Saúde. Adotou-se nível de significância de $5 \%$ para todos os testes estatísticos.

\section{Resultados}

A prevalência de deficiência de vitamina A (niveis de retinol <0,70umol/L) foi de 9,8\% (IC95\%=7,9-10,0). Verificaram-se maiores prevalências de niveis de retinol baixos ou aceitáveis $(<1,05 \mu \mathrm{mol} / \mathrm{L})$ em estudantes na faixa etária de 12-14 anos e que residiam em domicílios onde a água não era provida pela rede pública ( $p>0,05)$. Assim, ingerir água de poço ou de outra fonte não tratada foi o fator de maior impacto sobre a ocorrência de niveis mais baixos de retinol (OR=3,28; IC95\%=1,48-7,28; $p=0,003)$.

\section{Conclusão}

A deficiência de vitamina A caracterizou-se como problema de saúde pública leve entre os estudantes estudados, sinalizando a necessidade de direcionar ações que enfoquem esta problemática em escolares, bem como, de planejamento de estudos com amostras mais abrangentes para investigar o problema em âmbito municipal e estadual. A ingestão de água não tratada, possivelmente um veículo de infecção, contribuiu para menores valores de retinol.

Palavras-chave: Indicadores. Estudantes. Vitamina A. Deficiência de vitamina A.

\section{INTRODUCTION}

Although in decline, Vitamin A Deficiency (VAD) is still one of the great priorities regarding micronutrient deficiencies, which affect roughly 190 million children and 19.1 million pregnant women globally. VAD is classified as a moderate public health problem in 122 countries, including Brazil $[1,2]$.

From 1991 to 2013, VAD decreased significantly in Oceania, Southeast and East Asia, Latin America, and Caribbean, but not in South Asia and Sub-Saharan Africa, places where the deficiency still prevails [3]. Brazil does not have official data yet indicating a decrease in VAD, and VAD has been considered a public health problem in the North and Northeast regions, and in some parts of the Midwest and Southeast regions, affecting mainly preschoolers, pregnant women, and puerperal women [4-7].

Some Brazilian studies conducted in the last decade found that VAD also affects a considerable proportion of school-aged children and adolescents [8-10], groups that are not classically recognized as priorities regarding vulnerability to this deficiency. Nevertheless, the findings are justified by the fact that vitamin $A$ 
is strongly involved in physical growth, which can be intense in children and adolescents undergoing a growth spurt, a period that requires more vitamin $A[1,2,11]$ Additionally, children and adolescents are susceptible to cultural, social, and environmental influences, possibly promoting inappropriate eating habits and lower intake of dietary sources of vitamins and minerals [12] and contributing to the development of important deficiency-related conditions.

Vitamin A deficiency has a negative impact on children's and adolescents' health as even subclinical deficiency levels can cause significant repercussions, compromising growth, bone health, sexual maturation, response to infections, and visual health [13] increasing morbidity, and decreasing quality of life.

Given the above and also the absence of a nationwide survey revealing the extent of VAD in Brazilian children aged more than five years and adolescents, studies are needed to investigate $V A D$ frequency and the associated factors in these age groups. Thus, the present study aims to estimate the prevalence of VAD and analyze the socioeconomic and demographic factors associated with serum retinol levels in public school students aged eight to 14 years.

\section{METHODS}

This is a cross-sectional, descriptive, and analytical study of 245 students aged eight to 14 years attending four municipal elementary schools in Teresina (PI), a state in which VAD in preschoolers and pregnant adolescents is a moderate to severe public health problem $[7,14,15]$.

Sample size was calculated by considering the $8.9 \%$ prevalence of $V A D$ in students aged seven to 14 years from Salvador (BA) [10] the 32,000 students enrolled in the public schools of Teresina (PI) in 2011; an error margin of 5\%; and a design effect of 2 as the sampling method was not random simple but cluster. The required sample size was 249 students.

All four schools were located in the Northern area of the municipality, one in the rural area and three in the urban area. First, the area (North) was randomly selected, and then the schools, also randomly selected. Male and female students aged eight to 14 years attending the selected schools were eligible for the study. Students with fever on blood collection day or students taking vitamin or mineral supplements were excluded.

Data were collected between October 2011 and March 2012. The socioeconomic and demographic data were collected by administering a form to parents and guardians. The collected data included birth date, age, sex, school location (urban/rural), parents' education levels, family income, home construction material, home water supply and source, garbage disposal system, type of sewage, and number of household members.

Five milliliters of peripheral blood were collected by venipuncture to measure serum retinol. The blood was stored in a test tube without anticoagulant and wrapped in aluminum foil to minimize the loss of vitamin $A$ [14].

The blood samples were taken to the Laboratory of Experimental Nutrition of the Department of Nutrition of the Universidade Federal do Piauí (UFPI), where they were centrifuged to extract $1.0 \mathrm{~mL}$ of serum. The serum was placed in an amber-colored Ependorff microtube, which was frozen to $-80^{\circ} \mathrm{C}$ and sent to the Micronutrient Investigation Center of the Hospital Universitário Lauro Wanderley of the Universidade Federal da Paraíba.

Serum retinol was quantified by the liquid chromatographer LC-10Avp (Shimadzu Corporation, Analytical Instruments Division, Kyoto, Japan), consisting of a pump (SCL-10Avp), UV-VIS detector with deuterium lamp (SPD10Avp), and manual injector controlled by the software Class-vp 6.12 SP5. Chromatographic 
separation was performed by the reversedphase column C18 (Shimadzu LC Columm CLC-ODS "M" 25cm; 4.6mm ID X 25cm - 5um). The samples were prepared as follows for injection of $50 \mu \mathrm{L}$ in the High-Performance Liquid Chromatography (HPLC): thawing the serum to room temperature in the shade, pipetting $100 \mu \mathrm{L}$ of extraction solution (ethanol) and $50 \mu \mathrm{L}$ of serum in an amber-colored microtube, homogenizing and centrifuging the mixture, collecting roughly $90 \mu \mathrm{L}$ of the supernatant, and refrigerating it until HPLC injection [16].

The students' serum retinol status was classified according to the cut-off points provided by the World Health Organization [17] as follows: deficient (retinol $<0.70 \mu \mathrm{mol} / \mathrm{L}$ ); acceptable $(0.70 \leq$ retinol $<1.05 \mu \mathrm{mol} / \mathrm{L})$, and normal (retinol $\geq 1.05 \mu \mathrm{mol} / \mathrm{L}$ ). VAD was defined as serum retinol $<0.70 \mu \mathrm{mol} / \mathrm{L}$.

The software Stata ${ }^{\circledR}$ version 12 (Stata Corp, College Station, Texas, United States) organized and analyzed the data. The variables were analyzed descriptively and presented as means, proportions, and 95\% Confidence Intervals $(95 \% \mathrm{Cl})$.

The Shapiro-Wilk test assessed whether the quantitative variables had normal distribution. The Student's $t$-test compared the two means. Bivariate analysis used two categories of serum retinol: $<1.05 \mu \mathrm{mol} / \mathrm{L}$ and $\geq 1.05 \mu \mathrm{mol} / \mathrm{L}$. Pearson's Chi-square test $\left(\chi^{2}\right)$ or Fisher's exact test, when appropriate, tested associations between variables. The Odds Ratio (OR) with the $p$-values and $95 \% \mathrm{Cl}$ were used as measures of effect. Tests with $p \leq 0.05$ were considered statistically significant.

This study was approved by the Research Ethics Committee of the UFPI on July 1, 2011, under Protocol $n^{\circ}$ 0180.0.045.000-11, and all participants signed an Informed Consent Form before joining the study.

\section{R E S U L T S}

A total of 250 students were selected for the study, but five (2.0\%) were excluded because the amount of blood drawn was inadequate for analysis. Thus, the study assessed 245 students aged eight to 14 years enrolled in four municipal public schools. Most students were female (54.7\%) and aged 10 to 11 years (64.4\%). Table 1 shows the socioeconomic and demographic characteristics of the sample.

The students had a mean serum retinol of $\quad 1.18 \mu \mathrm{mol} / \mathrm{L} \quad(95 \% \mathrm{Cl}=1.12-1.24 \mu \mathrm{mol} / \mathrm{L})$, which did not differ between females $(1.17 \mu \mathrm{mo} / \mathrm{L}$; 95\% Cl=1.10-1.25 $\mu \mathrm{mol} / \mathrm{L})$ and males $(1.19 \mu \mathrm{mol} / \mathrm{L}$; $95 \% \mathrm{Cl}=1.10-1.29 \mu \mathrm{mol} / \mathrm{L}) \quad(p=0.762) \quad$ (data not tabulated). Figure 1 shows the normal distribution of students' serum retinol levels by sex.

Table 2 presents the students' serum retinol levels by sex and age group. The prevalence of $\operatorname{VAD}$ was $9.8 \% \quad(95 \% \mathrm{Cl}=7.9 \%-10.0 \%)$. A significant proportion of students $(36.3 \%$; $95 \% \mathrm{Cl}=26.0 \%-46.8 \%)$ had marginal retinol level, and $53.9 \%$ had normal retinol level (95\% Cl=46.4\%-63.5\%).

Serum retinol was significantly associated with age group $(p=0.003)$. The proportion of students with marginal retinol level increased with age, and the proportion of students with normal retinol level decreased with age. However, the proportion of students with VAD did not change with age. Serum retinol was not associated with sex ( $p=0.361)$ (Table 2$)$.

Table 3 shows the OR of retinol levels $<1.05 \mu \mathrm{mol} / \mathrm{L}$ by socioeconomic and demographic variables. Retinol levels $<1.05 \mu \mathrm{mol} / \mathrm{L}$ were uniformly distributed in males and females $(p=0.280)$. The proportion of students with retinol level $<1.05 \mu \mathrm{mol} / \mathrm{L}$ did not vary significantly by maternal education level $(O R=1.27 ; p=0.359)$, per capita income $(\mathrm{OR}=1.28 ; p=0.505)$, school location ( $\mathrm{OR}=0.78 ; p=0.474)$, home construction material $(O R=1.34 ; p=0.560)$, type of sewage (OR=0.97; $p=0.939$ ), or garbage disposal system $(\mathrm{OR}=0.57 ; p=0.177)$. However, students aged 12 to 14 years $(O R=0.12 ; p=0.001)$ and students without piped water supply at home $(O R=3.28$; $p=0.003$ ) were more likely to have serum retinol $<1.05 \mu \mathrm{mol} / \mathrm{L}$. 
Table 1. Distribution of students by socioeconomic and demographic variables (N=245). Teresina (PI), Brazil, 2016.

\begin{tabular}{|c|c|c|}
\hline Variables & $\mathrm{n}$ & $\%$ \\
\hline \multicolumn{3}{|l|}{ Sex } \\
\hline Male & 111 & 45.3 \\
\hline Female & 134 & 54.7 \\
\hline \multicolumn{3}{|l|}{ Age group (years) } \\
\hline 8 to 9 & 19 & 7.8 \\
\hline 10 to 11 & 158 & 64.4 \\
\hline 12 to 14 & 68 & 27.8 \\
\hline Mean $(95 \% \mathrm{Cl})$ & \multicolumn{2}{|c|}{11.0 years $(10.8-11.1$ years $)$} \\
\hline \multicolumn{3}{|l|}{ School location } \\
\hline Urban & 204 & 83.3 \\
\hline Rural & 41 & 16.7 \\
\hline \multicolumn{3}{|l|}{ Maternal education level* } \\
\hline Up to eight years & 120 & 49.2 \\
\hline >eight years & 124 & 50.8 \\
\hline Mean $(95 \% \mathrm{Cl})$ & \multicolumn{2}{|c|}{8.0 years in school ( $7.6-8.4$ years in school) } \\
\hline \multicolumn{3}{|l|}{ Per capita income } \\
\hline Income $\leq 1 / 4 \mathrm{MS}$ & 93 & 38.0 \\
\hline $1 / 4 \mathrm{MS}<$ income $\leq 1 / 2 \mathrm{MS}$ & 119 & 48.5 \\
\hline Income $>1 / 2 \mathrm{MS}$ & 33 & 13.5 \\
\hline Mean $(95 \% \mathrm{Cl})$ & \multicolumn{2}{|c|}{204.7 reais $(189.3-220.0$ reais) } \\
\hline \multicolumn{3}{|l|}{ Home construction material } \\
\hline Masonry (finished) & 143 & 58.4 \\
\hline Masonry (unfinished) & 85 & 34.7 \\
\hline Other & 17 & 6.9 \\
\hline \multicolumn{3}{|l|}{ Water source* } \\
\hline Piped water supply & 206 & 84.4 \\
\hline Well or other & 38 & 15.6 \\
\hline \multicolumn{3}{|l|}{ Type of sewage* } \\
\hline Sanitary sewer & 209 & 85.7 \\
\hline Other & 35 & 14.3 \\
\hline \multicolumn{3}{|l|}{ Garbage disposal system ${ }^{*}$} \\
\hline City collection service & 215 & 88.1 \\
\hline Other & 29 & 11.9 \\
\hline
\end{tabular}

Note: Note: MS: Minimum Salary $=\mathrm{R} \$ 622.00(2012) ;{ }^{*} \mathrm{n}=244$.

\section{I S C U S S I O N}

Some studies have already been conducted on VAD in preschoolers from the urban and rural areas of the municipality of Teresina (PI) $[14,15,18]$, confirming that VAD is a mild to moderate public health program in these areas.
The present study presents the first data on VAD in Teresina's (PI) children aged eight years or more and adolescents. Other studies conducted in municipalities or locations in the state of Piaui do not exist, and the present results should serve as evidence of the problem in one of the poorest regions of the country, 


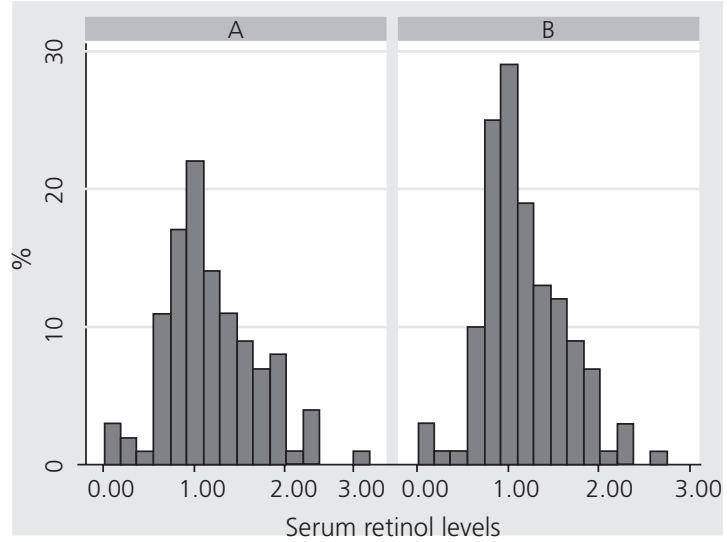

Figure 1. Distribution of serum retinol levels in the study male (A) and female (B) students. Teresina (PI), Brazil, 2016.

thus requiring extreme attention. In addition the data adds to the few Brazilian studies on this population group, contributing to the knowledge and understanding of the problem in population groups with possibly underestimated vulnerability to VAD.

The study vitamin A deficiency prevalence of $9.8 \%(95 \% \mathrm{Cl}=7.9 \%-10.0 \%)$ is characterized as a mild public health problem [1] approaching the prevalence rate that classifies the problem as a moderate public health problem (10.0\%), and confirming the trend also observed in preschoolers in the region $[14,15,18]$. Nevertheless, that frequency is lower than the percentages reported by nearly all studies on schoolers from other Brazilian regions [8-10,19-21]. Only Mariath et al. [22] reported a lower VAD prevalence (2.0\%) in children and adolescents monitored by a family health team in Itajai (SC).

The intake of dietary sources of vitamin A grown in the region, such as moriche palm fruit (Mauritia flexuosa), pequi (Caryocar brasiliense), mango, pumpkin, and squash, among others, may partly justify these findings. Yet, many studies would need to investigate the intake of these fruits and vegetables by students as this population group is not very fond of fruits and vegetables [12] In addition, the use of different analytical methods to measure serum retinol and different criteria to define insufficient or deficient vitamin A status prevents comparing the VAD prevalences reported by different studies.

By publishing order, Vitolo et al. [19] found a VAD prevalence of $10.1 \%$ in adolescents aged 10 to 19 years attending a private school of São Paulo by using spectrophotometry and a cut-off point of $<1.05 \mu \mathrm{mol} / \mathrm{L}$; 2); Ramalho et al. [20] found a VAD prevalence of $10.3 \%$ in students aged seven to 17 years attending a public school in Rio de Janeiro by using a cutoff point of $<1.05 \mu \mathrm{mol} / \mathrm{L}$; Santos et al. [21] found VAD prevalence of $29.0 \%$ in children aged six to 14 years attending a rural school in Minas Gerais by using spectrophotometry and defining inadequate serum retinol level as $<20 \mu \mathrm{g} / \mathrm{dL} \quad(<0.07 \mu \mathrm{mol} / \mathrm{L}) ;$ Graebner [8] found a VAD prevalence of $33.5 \%$ in students aged

Table 2. Distribution of students' serum retinol levels by sex and age group (N=245). Teresina (PI), Brazil, 2016.

\begin{tabular}{|c|c|c|c|c|c|c|c|}
\hline \multirow[t]{2}{*}{ Serum retinol } & \multicolumn{2}{|c|}{$\begin{array}{c}\text { Deficient } \\
(\mathrm{SR}<0.70 \mu \mathrm{mol} / \mathrm{L})\end{array}$} & \multicolumn{2}{|c|}{$\begin{array}{c}\text { Acceptable } \\
(0.70 \mu \mathrm{mol} / \mathrm{L} \leq \mathrm{SR}<1.05 \mu \mathrm{mol} / \mathrm{L})\end{array}$} & \multicolumn{2}{|c|}{$\begin{array}{c}\text { Normal } \\
(\mathrm{SR} \geq 1.05 \mu \mathrm{mol} / \mathrm{L})\end{array}$} & \multirow[t]{2}{*}{$p$} \\
\hline & $n$ & $\%$ & $n$ & $\%$ & $n$ & $\%$ & \\
\hline \multicolumn{8}{|l|}{ Sex } \\
\hline Male & 12 & 10.8 & 35 & 31.5 & 64 & 57.7 & \multirow{2}{*}{$0.361^{*}$} \\
\hline Female & 12 & 9.0 & 54 & 40.3 & 68 & 50.7 & \\
\hline \multicolumn{8}{|c|}{ Age group (years) } \\
\hline 8 to 9 & 2 & 10.5 & 1 & 5.3 & 16 & 84.2 & \multirow{4}{*}{$0.001^{* *}$} \\
\hline 10 to 11 & 15 & 9.5 & 53 & 33.5 & 90 & 57.0 & \\
\hline 12 to 14 & 7 & 10.3 & 35 & 51.5 & 26 & 38.2 & \\
\hline Total & 24 & 9.8 & 89 & 36.3 & 132 & 53.9 & \\
\hline
\end{tabular}

Note: ${ }^{*} \chi^{2}$ test; ${ }^{* *}$ Fisher's exact test; SR: Serum Retinol. 
Table 3. Odds Ratios (OR) of the prevalence of serum retinol level by socioeconomic and demographic characteristics. Teresina (PI), Brazil, 2016.

\begin{tabular}{|c|c|c|c|c|c|c|}
\hline \multirow{3}{*}{ Variables } & \multicolumn{4}{|c|}{ Retinol levels } & \multirow{3}{*}{${ }^{*} \mathrm{OR}_{\text {crude }}(95 \% \mathrm{Cl})$} & \multirow{3}{*}{$p$} \\
\hline & \multicolumn{2}{|c|}{$<1.05 \mu \mathrm{mol} / \mathrm{L}$} & \multicolumn{2}{|c|}{$\geq 1.05 \mu \mathrm{mol} / \mathrm{L}$} & & \\
\hline & $n$ & $\%$ & $n$ & $\%$ & & \\
\hline \multicolumn{7}{|l|}{ Sex } \\
\hline Male & 47 & 42.3 & 64 & 57.7 & 1 & \multirow{2}{*}{0.280} \\
\hline Female & 66 & 49.2 & 68 & 50.8 & $0.76(0.46-1.26)$ & \\
\hline \multicolumn{7}{|l|}{ Age group } \\
\hline $8-9$ years & 3 & 15.8 & 16 & 84.2 & 1 & \\
\hline $10-11$ years & 68 & 43.0 & 90 & 57.0 & $0.25(0.07-0.89)$ & 0.032 \\
\hline $12-14$ years & 42 & 61.8 & 26 & 38.2 & $0.12(0.03-0.44)$ & 0.001 \\
\hline \multicolumn{7}{|l|}{ Maternal education level } \\
\hline Up to eight years & 52 & 43.3 & 68 & 56.7 & 1 & \\
\hline >eight years & 61 & 49.2 & 63 & 50.8 & $0.79(0.48-3.31)$ & 0.359 \\
\hline \multicolumn{7}{|l|}{ Per capita income } \\
\hline$\leq 1 / 2 \mathrm{MS}$ & 96 & 45.3 & 116 & 54.7 & 1 & \\
\hline$>1 / 2 \mathrm{MS}$ & 17 & 51.5 & 16 & 48.5 & $0.78(0.37-1.62)$ & 0.505 \\
\hline \multicolumn{7}{|l|}{ School location } \\
\hline Urban & 92 & 45.1 & 112 & 54.9 & 1 & \\
\hline Rural & 21 & 51.2 & 20 & 48.8 & $0.78(0.40-1.53)$ & 0.474 \\
\hline \multicolumn{7}{|l|}{ Home construction material } \\
\hline Masonry (finished or not) & 104 & 45.6 & 124 & 54.4 & 1 & \\
\hline Other & 9 & 52.9 & 8 & 47.1 & $0.74(0.28-2.00)$ & 0.560 \\
\hline \multicolumn{7}{|l|}{ Water source } \\
\hline Piped water supply & 104 & 50.5 & 102 & 49.5 & 1 & \\
\hline Well or other & 9 & 23.7 & 29 & 76.3 & $3.28(1.48-7.28)$ & 0.003 \\
\hline \multicolumn{7}{|l|}{ Type of sewage } \\
\hline Sanitary sewer & 97 & 46.4 & 112 & 53.6 & 1 & \\
\hline Other & 16 & 45.7 & 19 & 54.3 & $1.03(0.50-2.11)$ & 0.939 \\
\hline \multicolumn{7}{|l|}{ Garbage disposal system } \\
\hline City collection service & 103 & 47.9 & 112 & 52.1 & 1 & \\
\hline Other & 10 & 34.5 & 19 & 65.5 & $1.75(0.78-3.93)$ & 0.177 \\
\hline
\end{tabular}

Note: MS: Minimum Salary: $\mathrm{R} \$=622.00$ (2012); ${ }^{*} \mathrm{OR}$ crude : Non-adjusted variables - bivariate analysis.

95\% Cl: $95 \%$ Confidence Interval.

five to 18 years from a rural area of the Federal District by using HPLC, which is considered the gold standard, and defining inadequate serum retinol level as $<20 \mu \mathrm{g} / \mathrm{dL}(<0.07 \mu \mathrm{mol} / \mathrm{L})$; Custódio et al. [9] found prevalences of $26.2 \%$ and $5.8 \%$ of serum retinol level $<1.05 \mu \mathrm{mol} / \mathrm{L}$ and $<0.70 \mu \mathrm{mol} / \mathrm{L}$, respectively, in children aged five to 11 years by using the Relative DoseResponse method; and finally, more recently, Ribeiro-Silva et al. [10] found a VAD prevalence of $27.8 \%$ in children and adolescents of a public school in Salvador (BA), by using a cut-off point of $<30 \mathrm{~g} / \mathrm{dL}$ or $<1.05 \mu \mathrm{mol} / \mathrm{L}$ and HPLC.

Of the biological and demographic characteristics, age influences the vitamin $A$ status of children aged less than five years, and vitamin A level tends to decrease with age [14]. The relationship between age and retinol level in students remains unclear. Ribeiro-Silva et al. [10] compared students aged less and more than 10 
years from Salvador (BA), and found a positive association between moderate/severe VAD and age. However, the present study results do not confirm that finding as low serum retinol level was more prevalent in students aged 12 to 14 years. These students were 0.12 times more likely to have low serum retinol than students aged 8 to 9 years $(p=0.001)$. More studies are needed on this subject because, from the physiological viewpoint, a growth spurt, which probably requires more vitamin $A$, is very complex and varies considerably between individuals, regardless of sex; additionally, the growth spurt depends on pubertal development, which is influenced by genetic and environmental factors, among others [23].

The last National Survey on the Demographics and Health of Women and Children [4] found that living in urban areas was associated with a higher prevalence of VAD. In contrast, the present study found that the proportions of students with VAD living in urban and rural areas did not differ. Even though the present study did not investigate the students' residence location, it assumed that students lived close to their schools. Other studies comparing VAD in children aged more than eight years or adolescents from urban and rural areas were not found, making this an important characteristic for future comparisons.

A growing number of studies in the scientific literature states that VAD does not depend on socioeconomic characteristics $[5,24]$ as VAD is also a reflex of eating habits and cultural aspects that influence food choices. Most study students' families were below the poverty line, defined as families with per capita income between $25 \%$ and $50 \%$ of the minimum salary, according to the methodology created by Hoffmann [25]. Even so, per capita income was not associated with VAD, corroborating other studies $[5,21]$.

Regarding basic sanitation, a higher proportion of low retinol levels was found in students living in homes without piped water supply, that is, piped water supply was the variable most strongly associated with low retinol levels in the study sample. This finding indicates that untreated water from wells or other sources is a source of waterborne illnesses, a determinant of low serum retinol [26].

Still, these observations must be interpreted with caution. Also, more studies are needed as the study sample is not representative of all the students aged eight to 14 years from Teresina. Future studies should investigate the association between water potability and serum vitamin $A$, and other important variables, such as food intake, for a better diagnosis of VAD in students.

\section{CONCLUSION}

The study prevalence of VAD in students aged eight to 14 years from urban and rural areas is considered a mild public health problem. Among the study socioeconomic and demographic variables, students aged more than 12 years and those whose homes had no piped water supply were more likely to have low serum retinol. These results indicate the need of society and government agencies directly or indirectly involved with public health to pay attention to this age group. Since this group is not considered at risk of vitamin A deficiency, it is not targeted by actions, policies, and programs dedicated to vitamin A prevention or treatment.

\section{CONTRIBUTORS}

ABM LIMA designed the study, collected and analyzed data, and approved the final version for publication. LS GARCÊZ analyzed data, wrote the article, and approved the final version for publication. IKF OLIVEIRA interpreted data, wrote the article, and approved the final version for publication. MM SANTOS designed the study and approved the final version for publication. SMRS PAZ and JM SILVA 
analyzed data, interpreted the results, and approved the final version for publication. AA PAIVA designed the study, collected and analyzed data, wrote the article, and approved the final version for publication.

\section{REFERE N CES}

1. World Health Organization. Global prevalence of vitamin A deficiency in populations at risk 1995-2005: WHO Global Database on vitamin A deficiency. Geneva: WHO; 2009.

2. Sherwin JC, Reacher MH, Dean WH, Ngondi J. Epidemiology of vitamin A deficiency and xerophthalmia in at-risk populations. Trans $\mathrm{R}$ Soc Trop Med Hyg. 2012;106(4):205-14. https://doi. org/10.1016/j.trstmh.2012.01.004

3. Stevens GA, Bennett JE, Hennocq Q, Lu Y, De-Regil LM, Rogers L, et al. Trends and mortality effects of vitamin A deficiency in children in 138 low-income and middle-income countries between 1991 and 2013: A pooled analysis of population-based surveys. Lancet. 2015;3(9):e528-e36. https://doi. org/10.1016/S2214-109X(15)00039-X

4. Ministério da Saúde (Brasil). Centro Brasileiro de Análise e Planejamento. Pesquisa Nacional de Demografia e Saúde da Criança e da Mulher. Série G. Estatística e Informação em Saúde. Brasília: Ministério da Saúde; 2009.

5. Queiroz D, Paiva ADA, Pedraza DF, Cunha MALD, Esteves GH, Luna JG, et al. Vitamin A deficiency and associated factors in children in urban areas. Rev Saúde Pública. 2013;47(2):248-56. https:// doi.org/10.1590/S0034-8910.2013047002906

6. Santos FTF, Andreto LM, dos Santos VCS, de Arruda IKG, da Silva DA. Serum retinol concentrations in mothers and newborns at delivery in a public maternity hospital in Recife, Northeast Brazil. J Health Popul Nutr. 2014;32(1):28-35.

7. Garcêz LS, Lima GSP, Paiva AA, da Paz SMRS, Gomes EIL, Nunes VS, et al. Serum retinol levels in pregnant adolescents and their relationship with habitual food intake, infection and obstetric, nutritional and socioeconomic variables. Nutrients. 2016;8(11):669. https://doi.org/10.3390/nu8110 669

8. Graebner IT. Níveis plasmáticos de vitamina A, ações pedagógicas e segurança alimentar: estudo em escolares rurais do Distrito Federal [tese]. Brasília: Universidade de Brasília; 2007.

9. Custódio VIC, Daneluzzi JC, Custódio RJ, del Ciampo LA, Ferraz IS, Martinelli CE Jr., et al. Vitamin A deficiency among Brazilian school-aged children in a healthy child service. Eur J Clin Nutr.
2009;63(4):485-90. https://doi.org/10.1038/sj.ejcn. 1602962

10. Ribeiro-Silva RC, Nunes IL, Assis AMO. Prevalence and factors associated with vitamin A deficiency in children and adolescents. J Pediatr. 2014;90(5):486-92. https://doi.org/10.1016/j.jped. 2014.01.014

11. Ramalho A, Padilha P, Saunders C. Análise crítica de estudos brasileiros sobre deficiência de vitamina A no grupo materno-infantil. Rev Paul Pediatr. 2008;26(4):392-9. https://doi.org/10.1590/S010 3-05822008000400014

12. Santos MM, Paiva AA, Pedrosa JIS, Viana RL. Dietary Knowledge, Behaviours and Attitudes of Students of Public School in a Northeastern City in Brazil. Health. 2014;6(11):1315-21. https://doi. org/10.4236/health.2014.611161

13. CouroucliXI. Vitamin A deficiency in adolescents: Rare or underdiagnosed? Lancet. 2016;387(10013):94. https://doi.org/10.1016/S0140-6736(15)00995-2

14. Paiva AA, Rondó PHC, Gonçalves-Carvalho CMR, Illison VK, Pereira JÁ, Vaz-de-Lima LRA, et al. Prevalência de deficiência de vitamina A e fatores associados em pré-escolares de Teresina, Piauí, Brasil. Cad Saúde Pública. 2006;22(9):1979-87. https://doi.org/10.1590/S010 2-311X2006000900029

15. Pereira JA, Paiva AA, Bergamaschi DP, Rondó PHC, Oliveira GC, Lopes IBM, et al. Concentrações de retinol e de beta-caroteno séricos e perfil nutricional de crianças em Teresina, Piauí, Brasil. Rev Bras Epidemiol. 2008;11(2):287-96. https:// doi.org/10.1590/S1415-790X2008000200010

16. Erhardt JG, Mack H, Sobeck U, Biesalski HK. $\beta$-Carotene and $\alpha$-tocopherol concentration and antioxidant status in buccal mucosal cells and plasma after oral supplementation. $\mathrm{Br} J$ Nutr. 2002;87(5):471-5. https://doi.org/10.1079/BJNBJN 2002566

17. World Health Organization. Indicators for assessing vitamin A deficiency and their application in monitoring and evaluating intervention programmes. Geneva: WHO; 1996.

18. Teles LFS. Deficiência de vitamina A e fatores relacionados à retinolemia em crianças de seis a cinquenta e nove meses de idade em assentamentos rurais de Teresina. Teresina [dissertação]. Universidade Federal do Piauí; 2016.

19. Vitolo MR, Gama CM, Queiroz SS, Lopez FA, Colugnati FAB. Retinol sérico de adolescentes de uma escola da cidade de São Paulo. Rev Nutr. 2004;17(3):291-9. https://doi.org/10.1590/ S1415-52732004000300002 
20. Ramalho RA, Saunders C, Natalizi DA, Cardoso LO, Accioly $E$. Níveis séricos de retinol em escolares de 7 a 17 anos no município do Rio de Janeiro. Rev Nutr. 2004;17(4):461-8. https://doi.org/10.1590/ S1415-52732004000400006

21. Santos MA, Rezende EG, Lamounier JÁ, Galvão MAM, Bonomo E, Leite RC. Hipovitaminose A em escolares da zona rural de Minas Gerais. Rev Nutr. 2005;18(3):331-9. https://doi.org/10.1590/ S1415-52732005000300005

22. Mariath AB, Giachini RM, Lauda LG, Grillo LP. Estado de ferro e retinol sérico entre crianças e adolescentes atendidos por equipe da Estratégia de Saúde da Família de Itajaí, Santa Catarina. Ciênc Saúde Coletiva. 2010;15(2):509-16. https:// doi.org/10.1590/S1413-81232010000200027

23. Coutinho MFG. Crescimento e desenvolvimento na adolescência. Rev Pediatr SOPERJ. 2011;12(Suppl.1):S28-34.
24. Ramalho RA, Flores H, Accioly E, Saunders C. Associação entre deficiência de vitamina $A$ e situação sociodemográfica de mães e recém-nascidos. Rev Assoc Med Bras. 2006;52(3):170-5. https://doi.org/10.1590/S0104-4230200600 0300018

25. Hoffmann RA. Distribuição de renda no Brasil no período 1993-99 [mimeografado]. Campinas: Universidade Estadual de Campinas; 2001.

26. Pedraza DF, Sales MC. Influência da inflamação subclínica sobre marcadores bioquímicos do estado nutricional de micronutrientes importantes no crescimento linear. Rev Ciênc Farm Básica Apl. 2015;36(1):103-9.

Received: December 22, 2016

Final version: April 11, 2017

Approved: May 18, 2017 